\title{
The Qatna lion: scientific confirmation of Baltic amber in late Bronze Age Syria
}

\author{
Anna J. Mukherjee ${ }^{1}$, Elisa Roßberger ${ }^{2 \dagger}$, Matthew A. James ${ }^{1}$, \\ Peter Pfälzner ${ }^{2}$, Catherine L. Higgitt ${ }^{3 \ddagger}$, Raymond White ${ }^{3}$, \\ David A. Peggie ${ }^{3}$, Dany Azar ${ }^{4,5} \&$ Richard P. Evershed ${ }^{1 *}$
}

Using pyrolysis-gas chromatography/mass spectrometry and Fourier transform infrared spectroscopy, the authors show that amber was imported into Late Bronze Age Syria and used for making the prestige artefacts found in a Royal tomb of c. 1340 BC. The objects included beads and a unique vessel in the form of a lion, likely fashioned in Syria from raw amber imported from the Baltic via the Aegean.

Keywords: Syria, Baltic, Qatna, Late Bronze Age, amber, lion

\section{Introduction}

The cultural importance of amber is evident from the many thousands of artefacts, especially pieces of personal adornment in the form of beads and amulets, found at New and Old World archaeological sites from late Palaeolithic times onwards (Grimaldi 1996: 145-8). In Europe, Baltic amber was particularly highly prized appearing to have been transported since the Neolithic, with trade routes emerging in the Bronze Age (Bouzek 1993). The occurrence of amber in the Ancient Near East, however, is rare and often ambiguous, with the earliest putative examples taking the form of singular beads dating to the first half of the second millennium BC (Moorey 1994: 79-81). The best known Egyptian pieces are the amber bead necklace and various other amber/resin jewellery items found in the tomb of Tutankhamun (Hood 1993) although, in common with the majority of such finds, they have not been chemically characterised, reflecting the challenging nature of the analysis of precious fossil resin (Anderson \& Winans 1991; Beck 1986; Beck et al. 1964; Langenheim 1969; Mills \& White 1994). Carved amber figurines, for which a large piece of raw material is needed, are extremely rare (cf. Beck 1979: 15).

\footnotetext{
1 Organic Geochemistry Unit, Bristol Biogeochemistry Research Centre, School of Chemistry, University of Bristol, Cantock's Close, Bristol BS8 1TS, UK

Altorientalisches Seminar, Schloß Hohentübingen, 72070 Tübingen, Germany

Scientific Department, National Gallery, Trafalgar Square, London WC2N 5DN, UK

Faculty of Science II, Natural Sciences Department, Lebanese University, Fanar, PO Box 26110217, Fanar-Matn, Lebanon

Muséum National d'Histoire Naturelle, Laboratoire d'Entomologie, 45 Rue Buffon, 75005 Paris, France

Current address: Institut für Vorderasiatische Archäologie, Ludwig-Maximilians-University Munich, Germany

$\ddagger \quad$ Current address: Department of Scientific Research, The British Museum, Great Russell Street, London WC1B $3 D G, U K$

* Author for correspondence
}

Received: 2 March 2007; Accepted: 23 April 2007; Revised: 9 July 2007

ANTIQUity 82 (2008): 49-59 


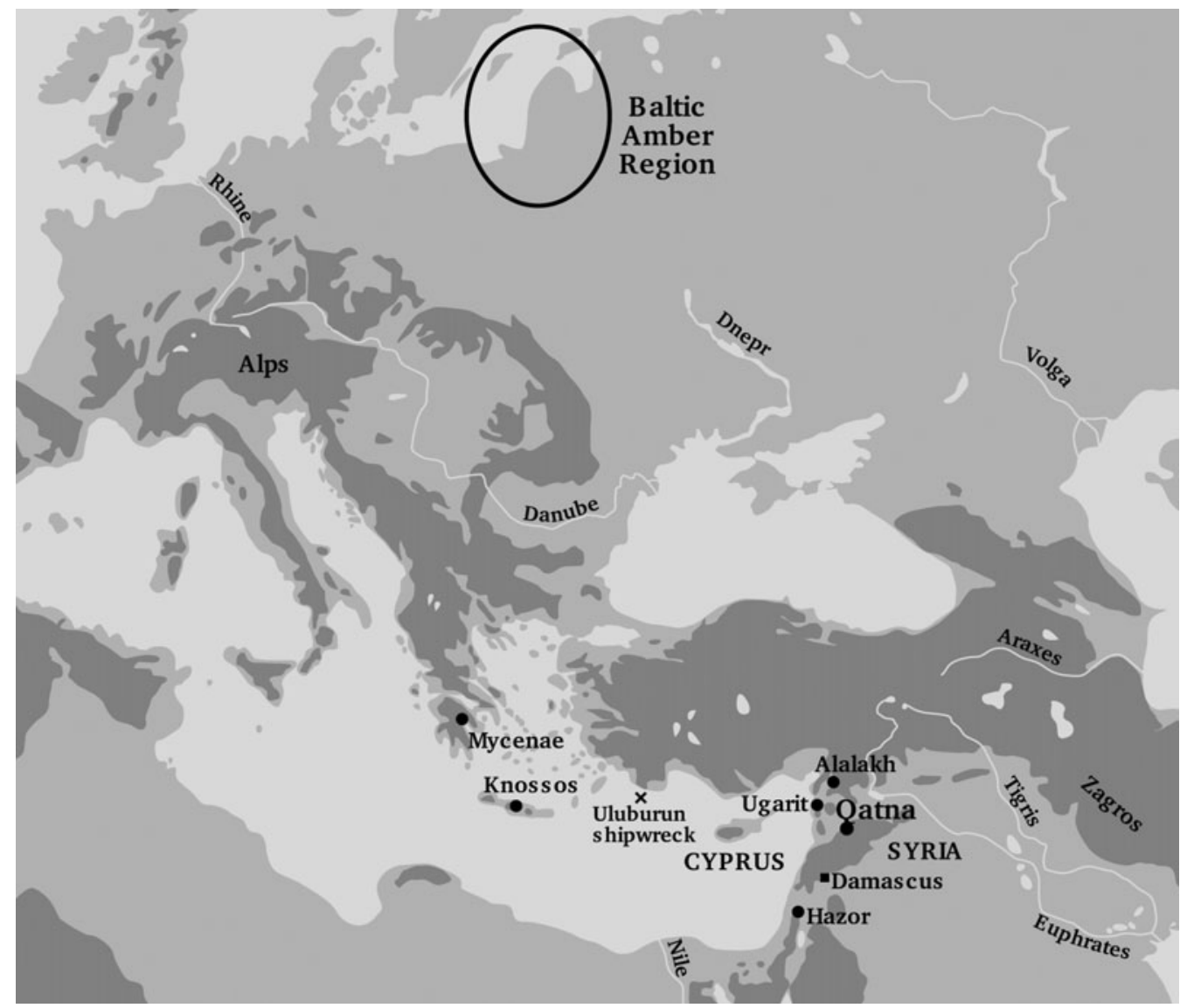

Figure 1. Map showing the location of Qatna and other sites mentioned in the text and the Baltic region.

One of the major questions relating to such finds is the origin of the amber used in their fashioning, which raises wider questions concerning interregional trade and gift exchange in antiquity. A Baltic amber source is often assumed, but Lebanese amber (Nissenbaum 1975), which is mainly Lower Cretaceous in age (c. 125 to $135 \mathrm{My}$ ), occurs mostly in Lebanon (275 outcrops) but also in Syria (Bloudan area), Israel (Kiryat Shmona) and Jordan (Wadi Zerqa).

\section{The Royal Tomb at Qatna}

Tell Mishrife is located $18 \mathrm{~km}$ north-east of Homs, and is the site of the ancient city of Qatna (Figure 1), which flourished for several centuries from around $1800 \mathrm{BC}$ (Al-Maqdissi et al. 2002), but was destroyed around $1340 \mathrm{BC}$ by an invading Hittite army (Pfälzner 2004). Although partially excavated in the 1920s (Du Mesnil du Buisson 1935), a German, Syrian and Italian venture was initiated in 1999 to further excavate the tell (Al-Maqdissi et al. 2002). During excavations in 2002 (joint Syrian-German mission directed by Michel Al-Maqdissi and Peter Pfälzner; Al-Maqdissi et al. 2002; 2003; Pfälzner 2004; 2006) an 
unlooted tomb was discovered (Figure 2a). Situated beneath the Royal Palace, the tomb had remained sealed since the destruction of the city, making $c .1340 \mathrm{BC}$ a terminus ante quem for the tomb and artefacts within. The contents of the burial chambers were remarkably well preserved, comprising almost 2000 finds including jewellery, bronzes, ivories, pottery and stone vessels, basalt statues, sarcophagi, human and animal bones. The range of finds and the architectural context indicate the tomb to have been in continuous use for 300-400 years as a royal burial chamber. Based on the tomb's inventory, ceremonies can be reconstructed involving 'kispum'; an ancient ritual where the dead were offered meals to maintain their positive powers for the afterlife (Al-Maqdissi et al. 2003; Pfälzner 2006). Several objects testify to the widespread exchange of raw materials, artistic ideas, techniques, and finished products in the Late Bronze Near East and Eastern Mediterranean (cf. Feldman 2006). Among the many finds were artefacts fashioned from a hard resin-like substance, including an intricately carved hollow lion head vessel (Figure $2 \mathrm{~b}$ and $2 \mathrm{c}$ ), an associated circular 'lid' (Figure $2 \mathrm{~b}$ and $2 \mathrm{e}$ ) and around 90 beads in various shapes (Figure 2f) including 45 from a triple-row gold-strung girdle (Figure $2 \mathrm{~d}$ ).

\section{Analytical procedures}

To investigate the nature of the material(s) used to fashion the objects and determine their origin, reference resins were selected as the most likely candidates: i.e. sandarac (polycommunic acid polymer), Congo copal (labdanoid polymer with enantio configuration), retinite (moderate retene amber with low succinic acid content), Prussian and Baltic ambers (from Pinites succinifera), Liquidambar orientalis (based on benzoic acid esters/styrene), Myrrh (triterpenoid resin) and schraufite (Lebanese amber).

Infrared spectroscopy is widely used in the analysis of ambers, and is particularly useful for the identification of Baltic amber (Anderson et al. 1992; Beck 1986; Beck et al. 1964; Langenheim 1969; Mills et al. 1984), but the small size of the Qatna samples made standard Fourier transform infrared (FTIR) measurements impossible. This problem was overcome by the use of a microscopic technique (see Technical Appendix).

Pyrolysis-gas chromatography/mass spectrometry (py-GC/MS) employing thermally assisted chemolysis with tetramethylammonium hydroxide (TMAH; Anderson \& Winans 1991) was also carried out on sub-samples of the artefacts and reference resins (see Technical Appendix). Peaks were identified based on their mass spectral characteristics, comparison with the NIST mass spectral library, GC retention indices and with reference to published data.

\section{Compositional analysis}

The FTIR spectra of the Qatna artefacts were most closely comparable to those obtained for reference Baltic and Prussian amber (Figure 3). The spectra are dominated by the amber polymer: a communic acid/communol co-polymer cross-linked by partial succinylation, and absorption maxima are seen at $c \cdot 1710-1740 \mathrm{~cm}^{-1}$ (ester and carboxylic acid carbonyl stretch), c. $1160 \mathrm{~cm}^{-1}$ (unesterified hydroxyl) and at $c .3040,1640$ and $885 \mathrm{~cm}^{-1}$ (exocyclic methylene). The characteristic shape of the Baltic amber (and certain North American 

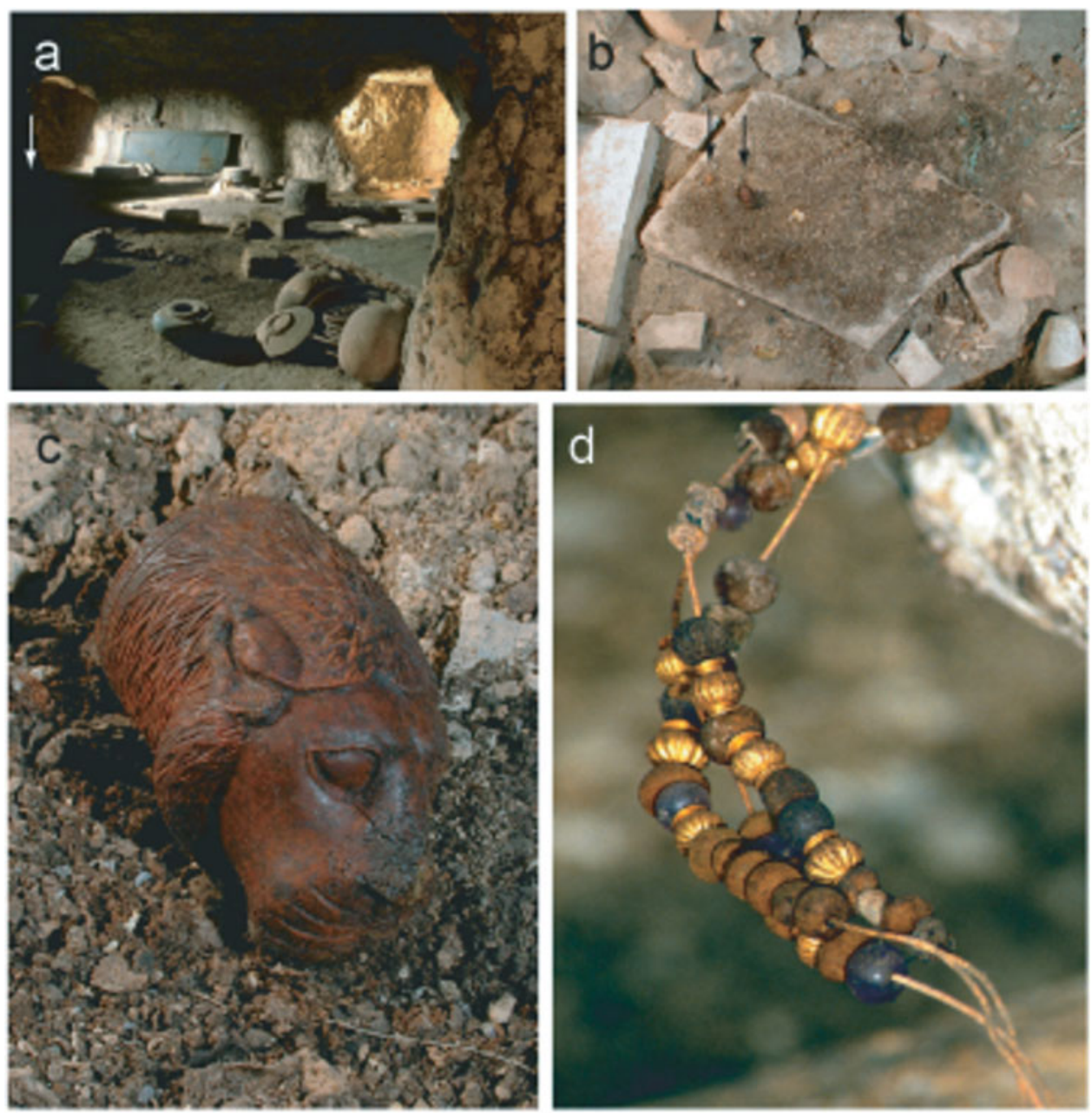

e

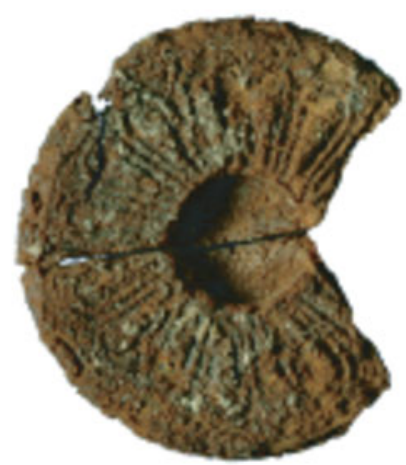

f

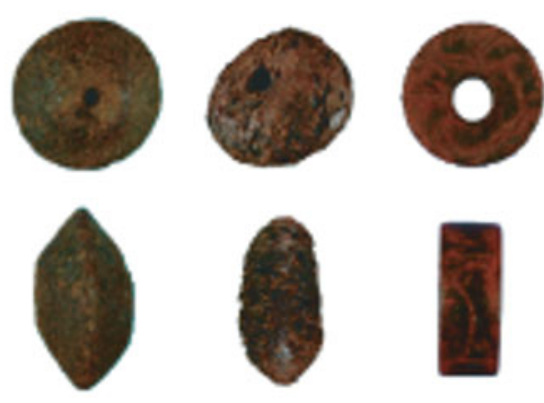

Figure 2. Photographs of the Qatna tomb and artefacts: (a) general view of the tomb, the location of the stone slab on which the lion head vessel and lid were found is indicated by an arrow; (b) a close up of the stone slab showing the lion head vessel and lid; (c) lion head vessel in situ shortly after discovery (MSH02G-i0759; size approx. $6.6 \mathrm{~cm}$ long $\times 5.9 \mathrm{~cm}$ wide 


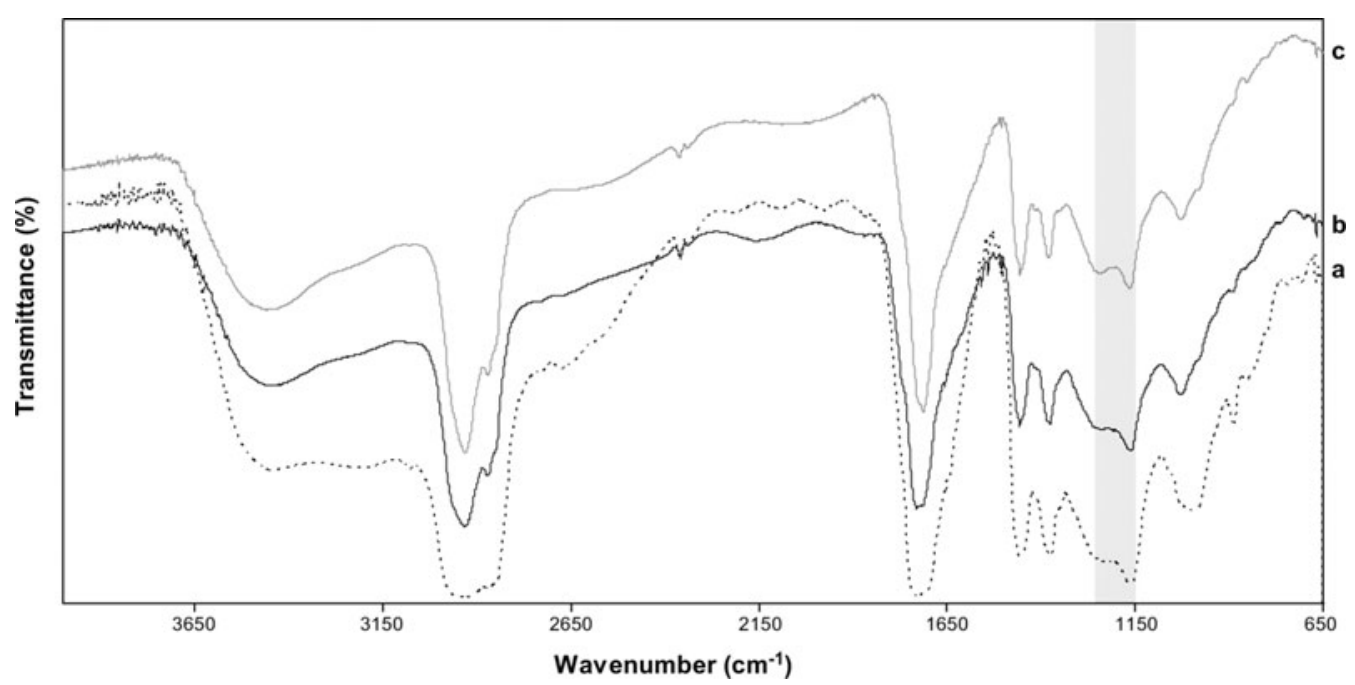

Figure 3. FTIR spectra of Qatna artefacts and reference Baltic amber: (a) reference Baltic amber (BM60828; dashed line); (b) lion head (solid black line); (c) bead (MSH04G q-i1448; solid grey line). The 'Baltic shoulder' is highlighted by the grey bar.

ambers) absorption band (including the 'Baltic shoulder') was clearly visible in the region 1250-1110 $\mathrm{cm}^{-1}$ (Anderson et al. 1992; Beck 1986; Beck et al. 1964; Langenheim 1969; Mills et al. 1984).

Py-GC/MS revealed an identical range of mono- and diterpenoid pyrolysis products for the lion head, lid and beads, confirming they are composed of the same material (Figure 4). Monoterpenoids, fenchol, borneol and other oxygenated terpenoids thought to form from pinene during the 'aging' of amber (Mosini et al. 1980) elute first (i.e. components 7 , 9, 10, 11, 13, 14 in Figure 4), together with the major pyrolysis product, succinic acid (4). Eluting later are carbomethoxylated drimane fragments (components 30, 32), resulting from pyrolytic cleavage of either the 9,11- or 11,12-bonds of communic acid type labdane structures (Anderson \& Winans 1991). The presence of these rule out a leguminosae source, as such resins are composed of polymer based on the enantio-series which would give isomeric fragments eluting at slightly longer retention times (as seen for Congo copal; data not shown). The latter sections of the pyrograms reveal diterpenoid esters (i.e. 40, 41, 43-48); including structures based on pimaric, abietic and agathic acids. According to the classification system of Anderson and co-workers (Anderson et al. 1992) the Qatna artefacts are composed of a Class 1a resinite, which include Baltic amber (and related European ambers), derived from resins based primarily on polymers of communic acid/communol. Substantial incorporation of succinic acid, probably serving as a cross linking agent, is characteristic (Mills et al. 1984). All Class 1 resinites also contain a small proportion of non

$x 4.7 \mathrm{~cm}$ high); (d) triple-row gold strung girdle with beads of amber, amethyst and gold; (e) lid for lion head vessel with rosette motif (MSH02G-i0766; diameter approx. 4cm); (f) examples of bead types, front and profile views (MSH02G-i1448 and MSH02G-i2329 analysed; diameters range from 0.8-2.8cm and lengths from 0.2-1.6cm). Not shown to scale. Photographs taken by K. Wita. Copyright Qatna-Project of the Altorientalisches Seminar of Tübingen University. 

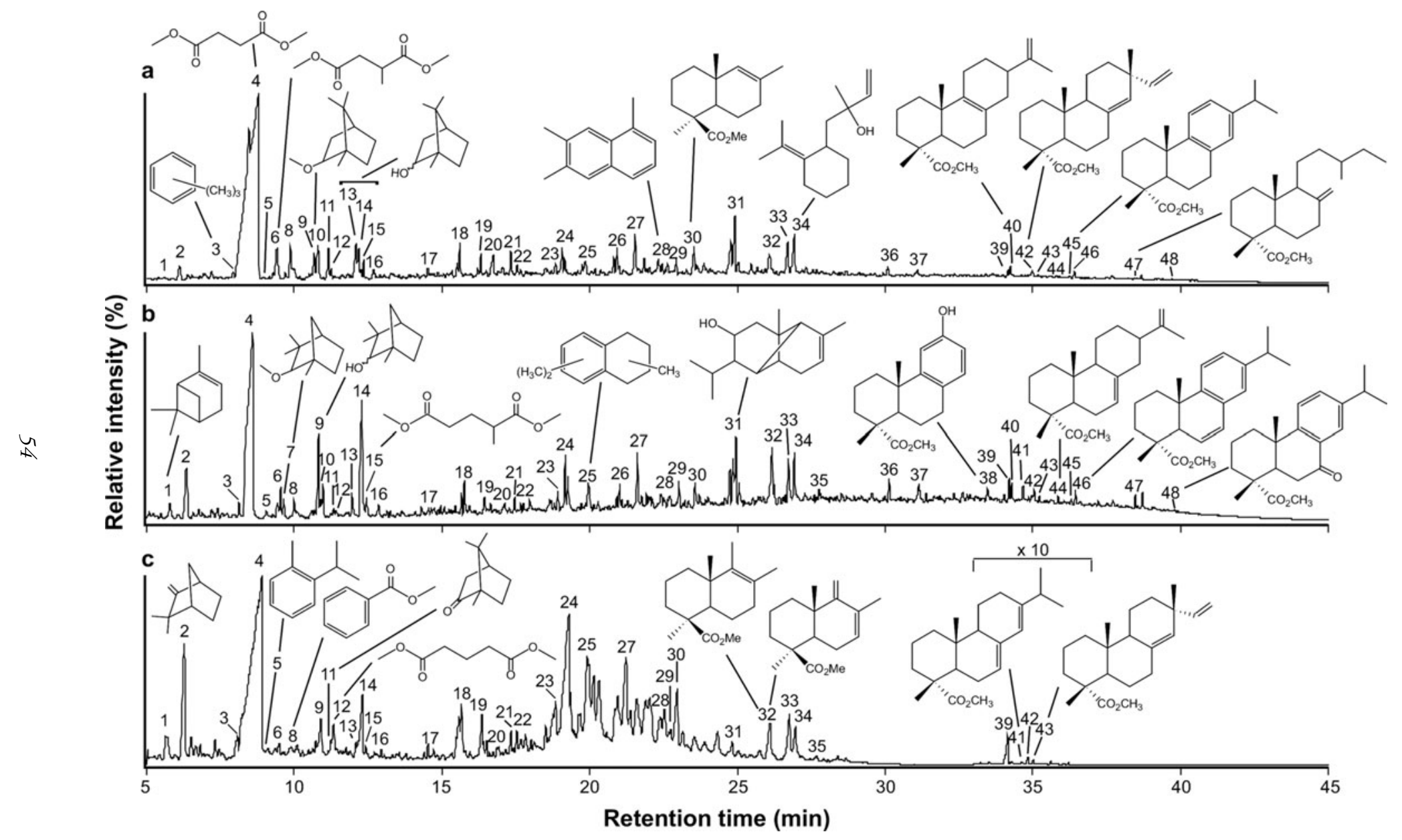

Figure 4. For caption see facing page. 
polymeric material (c. 20 per cent), including diterpenoid and labdanoid components of the type described above occluded within their macromolecular structure (Anderson et al. 1992; Gough \& Mills 1972).

With the exception of the Baltic and Prussian ambers, the MS and IR properties of reference resins differed markedly from the Qatna artefacts. The reference resins lacked characteristic markers of Baltic amber such as succinic acid, carbomethoxylated drimane fragments of communic acid type labdane structures, and the 'Baltic shoulder' in the IR spectra due to esters of succinic acid. Radiocarbon dating of a sub-sample of one of the beads (MSH04G-i1448) yielded an age of $45300 \pm 650$ uncalibrated radiocarbon years BP (OxA-V-2141-51), essentially infinite age (>40 000 years; Burleigh \& Whalley 1983), confirming that the bead was made from a fossil-sourced resin; Baltic amber is of Tertiary (Eocene/Oligocene) age (c. 40 My; Burleigh \& Whalley 1983).

While the pyrograms of the artefacts gave closely similar chemical 'fingerprints' (cf. Figure $3 \mathrm{a}$ and $\mathrm{b}$ ), the reference Baltic amber showed some variations (Figure 3c); lower abundances of the diterpenoids and higher proportions of pyrolysis products eluting in the region of 18 to $25 \mathrm{~min}$ were observed. Some differences between the reference amber and Qatna artefacts are not unexpected due to natural variation in the source material and oxidation of the artefacts. For example, the resin from the Qatna artefacts contained 7oxodehydroabietic acid (48), a well established oxidation product of abietic acid-containing diterpenoid resins, absent from the reference amber (van den Berg et al. 2000). The combined findings of FTIR, py-GC/MS and radiocarbon analysis confirm the Baltic origin of the amber used to fashion these artefacts; thus providing one of the few examples of chemically authenticated archaeological amber from the Near East.

\section{Discussion}

The quantity of amber in the Royal Tomb of Qatna is unparalleled for known second millennium BC sites in the Levant and the Ancient Near East. In Syria, to date, amber beads have only been discovered in small numbers in private graves at Alalakh (Woolley 1955: 203, 208), Mari (Jean-Marie 1999: 119, 120, 122, 144, 151, 153, 158, 162) and at the royal palace of Ugarit where 14 beads were found together with 'Mycenaean objects' (Schaeffer 1939: 100; Caubet 1998: 106). Except for the latter, these have neither been chemically analysed nor discussed in detail making their identification uncertain.

Figure 4. Partial total ion pyrograms of (a) lion head; (b) bead; (c) reference Baltic amber. Numbers indicate corresponding peaks in each pyrogram. Identified compounds are indicated by structures: (1) $\alpha$-pinene; (2) camphene; (3) trimethylbenzene; (4) succinic acid dimethyl ester; (5) o-cymene; (6) methyl succinic acid dimethyl ester; (7) $\alpha$-fenchyl methyl ether; (8) benzoic acid methyl ester; (9) fenchol; (10) bornyl methyl ether; (11) camphor; (12) pentanedioic acid dimethyl ester; (13/14) borneollisoborneol; (15) 2-methyl-pentanedioic acid dimethyl ester; (25) trimethylnaphthalene; (28) trimethylnaphthalene;

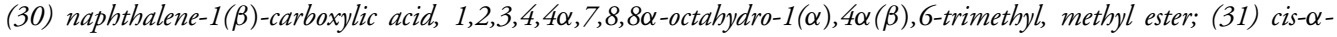
copaene-8-ol; (32) coeluting peaks of naphthalene-1( $\beta)$-carboxylic acid, 1,2,3,4,4 $\alpha, 7,8,8 \alpha$-octahydro-1 $(\alpha), 4 \alpha(\beta), 5,6-$ trimethyl, methyl ester and naphthalene-1( $\beta)$-carboxylic acid, 1,2,3,4,4 $\alpha, 7,8,8 \alpha$-octahydro- $1(\alpha), 4 \alpha(\beta), 6$-trimethyl-5methylene, methyl ester; (40) $\Delta^{8}$ isopimaric acid methyl ester; (41) methyl abietic acid; (43) sandaracopimaric acid/pimaric acid methyl ester; (44) isopimaric acid methyl ester; (45) methyl dehydrodehydroabietic acid; (46) methyl dehydroabietic acid; (47) dihydroagathic acid dimethyl ester; (48) 7-oxodehydroabietic acid methyl ester. 


\section{The Qatna lion}

It is at the beginning of the Mycenaean period (early sixteenth century BC) that Baltic amber, almost exclusively in the form of beads, reached the central Mediterranean, occurring in large numbers in the famous Shaft Graves of Mycenae and in a few other high-status burials on the Peloponnes (Harding \& Hughes-Brock 1974: 147-8; Harding 1984: 69-87). It remains a matter of debate as to how they came to be in the Aegean and whether amber reached ancient Greece as a raw material or finished product (Harding \& Hughes-Brock 1974: 154; Hughes-Brock 1993: 219, 221). While restricted to high status burials in the Mycenaean core area during this period, amber beads were distributed more widely in the fifteenth-thirteenth centuries BC, although the numbers present in any one single burial reduced dramatically (Harding \& Hughes-Brock 1974: 149-52). In the fourteenth and thirteenth centuries BC some amber beads reached the Eastern Mediterranean, notably Cyprus, Egypt, Syria and Palestine (Harding \& Hughes-Brock 1974; Hughes-Brock 1993; Hood 1993; Todd 1985; 1993). The 41 amber beads found in the Uluburun shipwreck off the Turkish coast, dating to the late fourteenth century BC, can either be interpreted within a context of trade, of gift exchange between royal elites, or as the personal belongings of high-ranking Mycenaeans onboard the vessel (Pulak 2005). A reputed amber bead necklace consisting of around 60 short biconvex to lentoid beads and various other putative amber objects from the tomb of Tutankhamun (Hood 1993), roughly contemporary with the latest phase of use of the Royal Tomb at Qatna, may hint at the high prestige value that was attributed to the material in Egypt at this time.

The lentoid and 'flattened globular' shapes of most of the amber beads from Qatna resemble Aegean and European examples very closely, possibly - but not unequivocally indicating a common place of manufacture, perhaps outside the Mediterranean in Central or Northern Europe (Harding \& Hughes-Brock 1974: 154; Harding 1984: 68-87). Importantly, however, some of the Qatna beads may well have been locally modified into a cylindric-disc shape (cf. Figure 2f); a form that also occurs in gold and lapis lazuli in Qatna's Royal Tomb but is not common elsewhere. The cylindric-disc beads of amber, lapis lazuli and gold match each other perfectly in size and shape and can most likely, considering their close association on the floor of the tomb, be reconstructed as elements of one necklace. Moreover, the fact that amber beads of appropriate size and shape were freely integrated into jewellery arrangements, such as the large gold-strung girdle (Figure 2d), rather than worn as necklaces consisting solely of amber beads as was common in the Aegean and Europe, makes their local reworking likely.

The lion head vessel along with its lid is an extremely rare, if not unique, example of figurative amber carving from the Ancient Near East and Eastern Mediterranean. Besides a small number of supposed amber scarabs from the Eighteenth Dynasty (Hood 1993: 230) and an amygdaloid engraved amber seal from Mycenae (Hughes-Brock 1993: 221), the only examples of figurative amber artefacts are two allegedly Neo-Assyrian statuettes of unknown provenance and highly disputed authenticity (Muscarella 2000: 177-8; Beck 1979) and a small lion figurine from Akhziv (Todd 1985: 293), probably dating to the ninth century BC.

Lions have long been part of Syrian, as well as Mesopotamian, Anatolian and Aegean royal iconography, and luxury or cultic vessels in the form of animal heads have occurred in the Eastern Mediterranean in the Middle and Late Bronze Age. Contemporary cuneiform 
texts from Mari, Alalakh, Ugarit and Qatna, as well as Hittite inventories mention vessels in the form of lion or bull heads made of silver and gold and destined for palatial and cultic use (Deller 1985; Otten 1989; cf. Zuckerman forthcoming).

Actual Late Bronze Age examples of lion head vessels are on the other hand quite rare. Neither the rather crudely made gold-sheet lion head found in Shaft Grave IV at Mycenae (Karo 1930: pl. CXVIII) nor the marble rython in the shape of a lioness from the palace at Knossos (Karo 1959: Figure 29) resemble the Qatna piece very closely. A lion head faience cup recently excavated in the destruction layer of the Late Bronze Age 'Ceremonial Palace/ Royal Sanctuary' of Hazor measures about $11 \mathrm{~cm}$ and offers one of the best parallels in form and potentially function even though its features are much less detailed in execution (Zuckerman forthcoming). Three lion head clay goblets attested at Ugarit (Yon 1997: 158-9; Schaeffer 1938: pl. XIX) show only limited stylistic resemblance to the Qatna piece; however, attention should be drawn to a lion-headed bronze axe-head from the same site (Schaeffer 1937: pl. XIX) which is remarkably comparable to the Qatna lion in terms of its overall facial proportions and the rendering of nose, whiskers and eyes. Depictions of lion head vessels on Egyptian wall-paintings in the Eighteenth-Dynasty tombs of Useramun, Mencheperasonb and Rechmire in Thebes are strikingly similar to the Qatna piece in terms of typology and style. These vessels are shown among objects characteristic of Syrian and Aegean origin and are painted in yellow indicating that they were made from gold (Wachsmann 1987: 58-9; Kantor 1947: pl. IX). Another similar vessel can be seen in a relief from Karnak depicting booty dedicated to Amun by Thutmosis III after his Syrian campaigns; it is placed among the most valuable offerings in one of the uppermost rows of the relief (Wachsmann 1987: 59, pl. LIII: 22). Although these depictions connect lion head vessels with both Syria and the Aegean, the style of the amber lion from Qatna suggests Syrian craftsmanship.

\section{Conclusion}

Hence, we conclude that the Qatna lion head vessel was manufactured from Baltic amber which was imported as a large unworked piece and subsequently carved, probably in a Syrian workshop, with Aegeans likely acting as intermediaries for the importation from Europe to the Near East. The raw material may have reached Qatna from the Aegean either through trade or as a result of gift exchange between ruling elites. Since large quantities of amber are restricted to very high status or even royal contexts at this time the latter, more exclusive way of acquisition, seems a more plausible interpretation. The unusual and attractive physical features of the material, the assumed awareness of its very distant provenance and the extremely long-distance exchange to attain it must have considerably added to its prestige value.

\section{Technical Appendix}

FTIR spectra were acquired using a Nicolet 710 Series FTIR spectrometer with NicPlan infrared microscope, fitted with a MCT Type A detector (cooled with liquid nitrogen), giving a working range of $4000-650 \mathrm{~cm}^{-1}$. Measurements were made in transmission mode, using a Spectra-Tech Reflachromat Cassegrain $\times 15$ objectives and a tube factor of $10 \times$. Typically 128 or 256 scans were made and the interferogram averaged. Scan velocity for the detector was $40 \mathrm{~cm} \mathrm{~s}^{-1}$, with a resolution of $4 \mathrm{~cm}^{-1}$ and Happ-Genzel apodisation. Both spectrometer and microscope were purged with air, which had been cleaned of particulates and hydrocarbons and was carbon 


\section{The Qatna lion}

dioxide and water-free, at between 1-2 $1 \mathrm{~min}^{-1}$. The sample was placed between the windows of a Spectra-Tech micro compression diamond cell.

For py-GC/MS analysis samples $(c .150 \mu \mathrm{g})$ were placed in quartz tubes and then pyrolysed at $610^{\circ} \mathrm{C}$ in a flow of helium for $10 \mathrm{~s}$ in a platinum coil using a CDS 1000 pyroprobe (Chemical Data System, Oxford, PA, USA) interfaced to a Perkin Elmer Turbomass Gold equipped with a fused silica capillary column (Chrompack; CP-Sil $5 \mathrm{CB} ; 50 \mathrm{~m} \times 0.32 \mathrm{~mm}$ i.d.; $0.12 \mu \mathrm{m}$ film thickness). The pyrolysate was introduced to the GC column via a split/splitless injector with a 20:1 split. The transfer line to the MS was held at $280^{\circ} \mathrm{C}$ and the source temperature maintained at $180^{\circ} \mathrm{C}$ and ionisation potential was set at $70 \mathrm{eV}$. The temperature programme comprised a $4 \mathrm{~min}$ isothermal period at $50^{\circ} \mathrm{C}$ followed by an increase to $300^{\circ} \mathrm{C}$ at $5^{\circ} \mathrm{C} \mathrm{min}^{-1}$. The temperature was then held at $300^{\circ} \mathrm{C}$ for $15 \mathrm{~min}$.

\section{Acknowledgements}

We thank Drs I.D. Bull and R. Berstan for technical assistance; the UK Natural Environment Research Council for funding the mass spectrometry facilities; the Wellcome Trust and the Engineering and Physical Sciences Research Council for providing a Bioarchaeology Fellowship for A.J.M. and a PhD studentship for M.A.J., respectively; the German Research Foundation for funding of the German component of the excavations at Tell Mishrife, ancient Qatna. Particular thanks are due to B. Jamous (Director General of Antiquities and Museums of Syria) and M. Al-Maqdissi (Director of Excavations in the Directorate General of Antiquities and Museums of Syria and co-director with P.F. of the Syrian-German Archaeological Mission at Tell Mishrife/Qatna) and Oxford University Radiocarbon Accelerator Unit for radiocarbon dating.

\section{References}

Al-Maqdissi, M., M. Luciani, D. Morandi Bonacossi, M. Novák \& P. Pfälzner. 2002. Excavating Qatna Voume 1 (Preliminary Report on the 1999 and 2000 Campaigns of the Joint Syrian-Italian-German Archaeological Research Project at Tell Mishrifeh) (Documents d'archéologie syrienne 4). Damascus: Direction Générale des Antiquités et des Musées de Syrie; Udine: University of Udine; Tübingen: University of Tübingen.

Al-Maqdissi, M., H. Dohmann-Pfälzner, P. Pfälzner \& A. Suleiman. 2003. Das königliche Hypogäum von Qatna. Mitteilungen der Deutschen Orient-Gesellschaft 135: 189-218.

Anderson, K.B. \& R.E. Winans. 1991. Nature and fate of natural resins in the geosphere 1. Evaluation of pyrolysis-gas chromatography mass-spectrometry for the analysis of natural resins and resinites. Analytical Chemistry 63: 2901-8.

Anderson, K.B., R.E. Winans \& R.E. Botto. 1992. The nature and fate of natural resins in the geosphere 2. Identification, classification and nomenclature of resinites. Organic Geochemistry 18: $829-41$.

Beck, C.W. 1979. Analysis of an 'Assyrian' amber statuette, in O. Muscarella (ed.) Unexcavated Objects and Ancient Near Eastern Art: Addenda (Monographic Journals of the Near East, Occasional Papers 1.1): 15-19. Malibu: IIMAS.

-1986. Spectroscopic investigations of amber. Applied Spectroscopy Reviews 22: 57-110.
Beck, C.W., E. Wilbur \& S. Meret. 1964. Infra-red spectra and the origin of amber. Nature 201: 256-7.

Bouzek, J. 1993. The shifts of the amber route, in C.W. Beck \& J. Bouzek (ed.) Amber in Archaeology (Proceedings of the Second International Conference on Amber in Archaeology, Liblice 1990, Institute of Archaeology): 141-6. Prague: Czech Academy of Sciences.

Burleigh, R. \& P. Whalley. 1983. On the relative geological ages of amber and copal. Journal of Natural History 17: 919-21.

Caubet, A. 1998. The international style: a point of view from the Levant and Syria, in E.H. Cline \& D. Harris-Cline (ed.) The Aegean and the Orient in the second millennium (Aegaeum 18): 105-11. Liège: Service d'histoire de l'art et d'archéologie de la Grèce antique \& Austin (TX): University of Texas.

Deller, K. 1985. SAG.DU UR.MAH, 'Löwenkopfsitula, Löwenkopfbecher'. Baghdader Mitteilungen 16: 327-46.

Du Mesnil du Buisson, R. 1935. Le site archéologique de Mishrifé-Qatna. Paris: de Boccard.

Feldman, M.H. 2006. Diplomacy by design: luxury arts and 'international style' in the Ancient Near East, 1400-1200 BCE. Chicago (IL): University of Chicago Press.

Grimaldi, D.A. 1996. Amber: window to the past. New York: Abrams.

Gough, L.J. \& J.S. MiLls. 1972. The composition of succinite (Baltic amber). Nature 239: 527-8.

Harding, A.F. 1984. The Mycenaeans and Europe. London: Academic Press. 
Anna J. Mukherjee et al.

Harding, A.F. \& H. Hughes-Brock. 1974. Amber in the Mycenaean world. Annual of the British School at Athens 69: 145-72.

Hood, S. 1993. Amber in Egypt, in C.W. Beck \& J. Bouzek (ed.) Amber in Archaeology (Proceedings of the Second International Conference on Amber in Archaeology, Liblice 1990, Institute of Archaeology): 230-35. Prague: Czech Academy of Sciences.

Hughes-Brock, H. 1993. Amber in the Aegean in the Late Bronze Age: some problems and perspectives, in C.W. Beck \& J. Bouzek (ed.) Amber in Archaeology. (Proceedings of the Second International Conference on Amber in Archaeology, Liblice 1990, Institute of Archaeology): 219-29. Prague: Czech Academy of Sciences.

Jean-Marie, M. 1999. Tombes et nécropoles de Mari. Beirut: Institut Français d'Archéologie du Proche Orient.

Kantor, H. 1947. The Aegean and the Orient in the second Millennium BC. American Journal of Archaeology 51: 1-103.

Karo, G. 1930. Die Schachtgräber von Mykenai. Munich: F. Bruckmann.

-1959. Greifen am Thron. Erinnerungen an Knossos. Baden-Baden: Grimm.

LANGenheim, J.H. 1969. Amber - a botanical inquiry. Science 163: 1157-69.

Mills, J.S. \& R. White. 1994. The organic chemistry of museum objects: 95-128. Oxford: ButterworthHeinemann.

Mills, J.S., R. White \& L.J. Gough. 1984. The chemical composition of Baltic amber. Chemical Geology 47: 15-39.

Moorey, P.R.S. 1994. Ancient Mesopotamian materials and industries: the archaeological evidence. Oxford: Oxford University Press.

Mosini, V., M.L. Forcellese \& R. Nicoletti. 1980. Presence and origin of volatile terpenes in succinite. Phytochemistry 19: 679-80.

Muscarella, O. 2000. The Lie Became Great: the Forgery of Near Eastern Cultures (Studies in the Art and Archaeology of Antiquity I). Groningen: Styx Publications.

Nissenbaum, A. 1975. Lower cretaceous amber from Israel. Naturwissenschaften 62: 341-2.
Otten, H. 1989. Tiergefäße im Kult der späten Hethitischen Großreichszeit, in K. Emre, B. Hrouda, M. Mellink \& N. Özgüç (ed.) Anatolia and the Ancient Near East: Studies in honour of Tahsin Ozgüç: 365-8. Ankara: Türk Tarih Kurumu Basmevi.

PFÄLzner, P. 2004. The world of the living and the world of the dead. German Research 26: 16-20.

-2006 . Syria's royal tombs uncovered. Current World Archaeology 15: 12-22.

Pulak, C. 2005. Who were the Mycenaeans aboard the Uluburun Ship?, in R. Laffineur \& E. Greco (ed.) Emporia, Aegeans in the Central and Eastern Mediterranean (Aegaeum 25): 295-312. Liège: Liège University.

Schaeffer, C.F.A. 1937. Les fouilles de Ras Shamra-Ugarit: huitième campagne (printemps 1936): rapport sommaire. Syria 18: 125-54.

-1938. Les fouilles de Ras Shamra-Ugarit: neuvième campagne (printemps 1937): rapport sommaire. Syria 19: 193-255.

-1939. Ugaritica I. Paris: Librairie Orientaliste Paul Geuthner.

TodD, J.M. 1985. Baltic amber in the ancient Near East: a preliminary investigation. Journal of Baltic Studies 16: 292-301.

-1993 . The continuity of amber artifacts in ancient Palestine from the Bronze Age to the Byzantine, in C.W. Beck \& J. Bouzek (ed.) Amber in Archaeology. (Proceedings of the Second International Conference on Amber in Archaeology, Liblice 1990, Institute of Archaeology): 236-48. Prague: Czech Academy of Sciences.

van den Berg, K.J., J.J.Boon, I. Pastorova \& L.F.M. SPETTER. 2000. Mass spectrometric methodology for the analysis of highly oxidized diterpenoid acids in Old Master paintings. Journal of Mass Spectrometry 35: 512-33.

Wachsmann, S. 1987. Aegeans in the Theban Tombs (Orientalia Lovaniensia Analecta 20). Leuven: Peeters.

Woolley, L. 1955. Alalakh. An account of the excavations at Tell Achana in the Hatay, 1937-1949 (Society of Antiquaries of London Research Reports 18). London: Society of Antiquaries of London.

Yon, M. 1997. La Cité d'Ougarit sur le Tell de Ras Shamra. Paris: Recherche sur les Civilisations.

Zuckerman, S. Forthcoming. Fit for a (not-quite-so-great) king: a faience lion-head cup from Hazor. 